\title{
O gênero Senna (Leguminosae, Caesalpinioideae) no Rio Grande do Sul, Brasil
}

\author{
Rodrigo Schütz Rodrigues ${ }^{1,3}$, Andréia Silva Flores ${ }^{1}$, Sílvia Teresinha Sfoggia Miotto $^{2}$ e \\ Luís Rios de Moura Baptista ${ }^{2}$
}

Recebido em 03/02/2004. Aceito em 12/07/2004

\begin{abstract}
RESUMO - (O gênero Senna (Leguminosae, Caesalpinioideae) no Rio Grande do Sul, Brasil). Este trabalho apresenta o estudo taxonômico do gênero Senna para o Rio Grande do Sul, Brasil. São encontradas 19 espécies, sendo que Senna aphylla (Cav.) H.S. Irwin \& Barneby, S. araucarietorum H.S. Irwin \& Barneby, S. pendula (Willd.) H.S. Irwin \& Barneby, S. scabriuscula (Vogel) H.S. Irwin \& Barneby e S. spectabilis (DC.) H.S. Irwin \& Barneby são registradas pela primeira vez para a flora do Estado. São apresentadas chave analítica, descrições e ilustrações para as espécies. Além disso, são fornecidos dados sobre a distribuição geográfica, hábitat, nomes vulgares e importância econômica das espécies estudadas.
\end{abstract}

Palavras-chave: Leguminosae, Caesalpinioideae, Senna, taxonomia, Rio Grande do Sul, Brasil

\begin{abstract}
The genus Senna (Leguminosae, Caesalpinioideae) in Rio Grande do Sul State, Brazil). This paper presents a taxonomic study of the species of the genus Senna occurring in Rio Grande do Sul State, Southern Brazil. Nineteen species were found and the occurences of Senna aphylla (Cav.) H.S. Irwin \& Barneby, S. araucarietorum H.S. Irwin \& Barneby, S. pendula (Willd.) H.S. Irwin \& Barneby, S. scabriuscula (Vogel) H.S. Irwin \& Barneby and S. spectabilis (DC.) H.S. Irwin \& Barneby are recorded for the first time in Rio Grande do Sul. Analitical key, species descriptions and illustrations are presented. Additional informations are provided concerning geographic distribution, habitats, common names and economic uses.
\end{abstract}

Key words: Leguminosae, Caesalpinioideae, Senna, taxonomy, Rio Grande do Sul, Brazil

\section{Introdução}

O gênero Senna Mill. pertence à tribo Cassieae Bronn, subtribo Cassinae Irwin \& Barneby (Irwin \& Barneby 1981). A subtribo Cassinae compreende três gêneros: Cassia L., Senna e Chamaecrista Moench (Irwin \& Barneby 1982). As espécies de Chamaecrista e Senna eram incluídas em Cassia s.l. até o tratamento taxonômico de Irwin \& Barneby (1981), quando estes gêneros foram separados. Senna distingue-se de Cassia principalmente pelos filetes retos, mais curtos ou até duas vezes o comprimento das anteras, pelas anteras basifixas e pela presença de nectários extraflorais na maioria das espécies. Por outro lado, Senna difere de Chamaecrista principalmente pela ausência de bractéolas (excepcionalmente presentes), pelo androceu zigomorfo e pelos legumes que podem ser indeiscentes (Irwin \& Barneby 1982).
Senna é gênero pantropical com 260 espécies, das quais 200 ocorrem no continente americano. Irwin \& Barneby (1982) revisaram as espécies americanas de Senna, citando sete espécies para o Rio Grande do Sul. No Estado, as espécies do gênero foram tratadas sob Cassia s.l. por Mattos (1983), que citou 21 espécies, sendo que 13 destas são atualmente incluídas em Senna.

O presente estudo teve como objetivo a determinação do número e da identidade das espécies nativas e exóticas de Senna ocorrentes no Rio Grande do Sul, com base no reconhecimento de sua variação regional.

\section{Material e métodos}

O estudo taxonômico se realizou de acordo com a metodologia clássica. Os herbários estudados foram

\footnotetext{
${ }^{1}$ Universidade Estadual de Campinas, Instituto de Biologia, Departamento de Botânica, C. Postal 6109, CEP 13083-970, Campinas, São Paulo, Brasil

2 Universidade Federal do Rio Grande do Sul, Instituto de Biociências, Departamento de Botânica, Av. Bento Gonçalves, 9500, Prédio 43433, CEP 91501-970, Porto Alegre, Rio Grande do Sul, Brasil

3 Autor para correspondência: rodrigo.schutz@itelefonica.com.br
} 
citados de acordo com as siglas estabelecidas no Index Herbariorum (Holmgren et al. 1990): BLA, HAS, HBR, HURG, ICN, MPUC, PACA, PEL, SMDB, UEC. Além disso, foram examinadas coleções dos herbários CNPO (Herbário do Centro Nacional de Pesquisas de Ovinos, Embrapa, Bagé, RS, Brasil), HERULBRA (Herbário da Universidade Luterana do Brasil, Canoas, RS, Brasil), HUCS (Herbário, Museu de Ciências Naturais, Universidade de Caxias do Sul, RS, Brasil), HUI (Herbário, Universidade de Ijuí, Ijuí, RS, Brasil) e UNILASALLE (Herbário, Universidade La Salle, Canoas, RS, Brasil). Os exemplares coletados pelos autores foram depositados nos herbários ICN e UEC.

As descrições do gênero e das espécies foram baseadas no material coletado no Rio Grande do Sul. A terminologia utilizada para as descrições foi baseada em Irwin \& Barneby (1982). As citações das obras estão de acordo com o Botanico-PeriodicumHuntianum (Lawrence et al. 1968), BotanicoPeriodicum-Huntianum/Supplementum (Bridson \& Smith 1991) e Taxonomic Literature (Stafleu \& Cowan 1976-1988) e as autoridades, segundo Brummit \& Powell (1992).
No item material selecionado foi citada somente uma coleção por município. A listagem completa dos materiais analisados pode ser obtida com os autores.

\section{Resultados e discussão}

Senna Mill.,Gard. Dict. abr. ed. 4. 1754.

Árvores, arbustos ou subarbustos. Folhas paripinadas, 1-multijugas, raro escamiformes; folíolos opostos; ráquis foliar e pecíolo com ou sem glândulas; estípulas de formas variadas, persistentes ou caducas. Flores amarelas ou alaranjadas, dispostas em racemos ou panículas; brácteas caducas ou persistentes; bractéolas ausentes; cálice com 5 sépalas, desiguais; corola zigomorfa ou assimétrica, com 5 pétalas; androceu com 6 ou 7 estames férteis em dois grupos heteromorfos, com anteras poricidas e 3 estaminódios adaxiais; ovário glabro ou pubescente. Legumes cilíndricos, comprimidos ou quadrangulares, retos ou curvos, endocarpo seco ou pulposo, deiscentes ou indeiscentes. Sementes 1-2-seriadas, rômbicas, ovais, oblongas ou orbiculares, castanhas, negras ou oliváceas.

Chave para a identificação das espécies ocorrentes no Estado do Rio Grande do Sul, Brasil

1. Plantas com folhas reduzidas a escamas 2. S. aphylla

1. Plantas com folhas não reduzidas a escamas

2. Folhas sem glândulas na base do pecíolo e/ou entre os folíolos

3. Folíolos 4-8,5cm larg.; estípulas triangulares, base auriculada; brácteas $18-22 \mathrm{~mm}$ compr. ...... 1. S. alata

3. Folíolos menores que $2,5 \mathrm{~cm}$ larg.; estípulas subuladas ou lineares; brácteas $3,5-4 \mathrm{~mm}$ compr.

4. Corola zigomorfa; estames latero-abaxiais com filetes de $8-12 \mathrm{~mm}$ compr.; legumes comprimidos; estípulas $1 \mathrm{~mm}$ compr. 18. S. siamea

4. Corola assimétrica; estames latero-abaxiais com filetes de 2,2-2,5mm compr.; legumes quadrangulares; estípulas 4-7mm compr. 19. S. spectabilis

2. Folhas com glândulas na base do pecíolo e/ou entre os folíolos

5. Glândulas na base do pecíolo e às vezes também entre os folíolos

6. Estame centro-abaxial não reduzido a estaminódio 12. S. oblongifolia

6. Estame centro-abaxial reduzido a estaminódio

7. Brácteas até $4 \mathrm{~mm}$ compr.; bico das anteras latero-abaxiais $0,5-1 \mathrm{~mm}$ compr.; estípulas linear-lanceoladas

8. Folíolos oblanceolados, obtrulados, raro oblongo-elípticos ou elípticos; legumes 0,8-1,2cm larg., não torcidos em espiral 11. S. neglecta

8. Folíolos ovais, oval-lanceolados ou elípticos; legumes $0,3-0,6 \mathrm{~cm}$ larg., torcidos 1-2 vezes em espiral 6. S. hirsuta

7. Brácteas 5-13mm compr.; bico das anteras latero-abaxiais 1,5-2mm compr.; estípulas triangulares

9. Brácteas 8-13mm compr.; pecíolo (1,5-)1,7-4,5cm compr. 14. S. occidentalis

9. Brácteas $5-7 \mathrm{~mm}$ compr.; pecíolo $0,8-1,8(-2,2) \mathrm{cm}$ compr. 17. S. scabriuscula

5. Glândulas somente entre os folíolos 
10. Subarbustos até $15 \mathrm{~cm}$ alt.; 1(-2) par(es) de folíolos

10. S. nana

10. Subarbustos, arbustos ou árvores maiores de $30 \mathrm{~cm}$ alt.; 2 ou mais pares de folíolos

11. Folhas com 9-23 pares de folíolos; corola assimétrica

9. S. multijuga

11. Folhas até 9 pares de folíolos; corola zigomorfa

12. Folhas somente com 2 pares de folíolos

13. Subarbustos prostrados ou decumbentes; racemos com 2-3 flores; legumes comprimidos, $0,3-0,8 \mathrm{~cm}$ larg.

16. S. pilifera

13. Árvores ou arvoretas; racemos com 7-20 flores; legumes cilíndricos, 1,4-2 cm larg.

8. S. macranthera

12. Folhas de 2-9 pares de folíolos

14. Pedúnculos até $5 \mathrm{~mm}$ compr.; legumes comprimidos

15. Pétalas $7-12 \mathrm{~mm}$ compr.

13. S. obtusifolia

15. Pétalas $26-33 \mathrm{~mm}$ compr

7. S. leiophylla

14. Pedúnculos maiores de $16 \mathrm{~mm}$ compr.; legumes cilíndricos

16. Folhas com 2-4 pares de folíolos; anteras abaxiais isomórficas em diâmetro e comprimento; legumes com sementes 1-seriadas

17. Folíolos 2,1-3,2cm larg., com base cuneada e ápice predominantemente acuminado 3. S. araucarietorum

17. Folíolos 0,7-2,2cm larg., com base oblíqua ou obtusa e ápice agudo, obtuso ou retuso

4. S. corymbosa

16. Folhas com (3-)4-9 pares de folíolos; anteras abaxiais anisomórficas

em diâmetro e/ou comprimento; legumes com sementes 2-seriadas

18. Folíolos 0,2-1 cm larg.; estames latero-abaxiais com filetes de 5-8,5mm compr.; gineceu 10-14mm compr.

5. S. hilariana

18. Folíolos 1-2,2cm larg.; estames latero-abaxiais com filetes de $14-24 \mathrm{~mm}$ compr.; gineceu $20-32 \mathrm{~mm}$ compr.

15. S. pendula

1. Senna alata (L.) Roxb., Fl. ind. 2: 349. 1824.

Cassia alata L., Sp. pl. 378. 1753.

Fig. 1-2.

Arbustos, eretos, 1-2m alt., ramos glabros ou pubérulos. Estípulas triangulares, base auriculada, 6-10mm compr. Folhas 7-11 pares de folíolos, $22-50 \mathrm{~cm}$ compr.; pecíolo 0,6-2cm compr.; glândulas ausentes, folíolos obovados ou oblongos, ápice arredondado, obtuso ou retuso, base oblíqua, folíolo distal $5,5-13 \times 4-8,5 \mathrm{~cm}$, face adaxial glabra ou glabrescente e abaxial puberulenta. Racemos axilares, 20-30 flores; pedúnculo 7,2-13,5cm compr.; brácteas obovadas, apiculadas, de $18-22 \mathrm{~mm}$ compr., caducas. Pedicelo $5-12 \mathrm{~mm}$ compr. Sépalas $10,5-16 \mathrm{~mm}$ compr.; corola zigomorfa, amarelo-ouro, pétalas $15-24 \mathrm{~mm}$ compr.; 4 estames medianos com filetes $2,5-3,7 \mathrm{~mm}$ compr. e anteras 3,3-5mm compr., estames abaxiais com anteras anisomórficas, estame centro-abaxial com filete $7-8,3 \mathrm{~mm}$ compr. e antera $4-5 \mathrm{~mm}$ compr., 2 estames latero-abaxiais com filetes $3-4,5 \mathrm{~mm}$ compr. e anteras $8-11,6 \mathrm{~mm}$ compr., bico $1 \mathrm{~mm}$ compr.; gineceu $13-21 \mathrm{~mm}$ compr., ovário pubescente. Legumes quadrangulares, alados, endocarpo seco, ascendentes, retos, glabros ou pubérulos, $12-14 \times 1,1-2 \mathrm{~cm}$. Sementes 2 -seriadas, rômbicas, castanhas ou oliváceas, $5-6 \times 3-5 \mathrm{~mm}$.

Material selecionado: BRASIL. Rio Grande do Sul: Canoas, Fátima, 19/I/2001, fl., Flores \& Rodrigues 462 (ICN, UEC); Igrejinha, 27/III/1959, fl. fr., Bauer s.n. (ICN 2018); Porto Alegre, Assunção, IV/1971, fr., Girardi s.n. (ICN 8035).

Espécie conhecida popularmente como "candelabro", sendo pouco cultivada como ornamental no Estado. Segundo Dimitri \& Alberti (1954), as folhas novas são purgantes, diuréticas, febrífugas e sudoríficas. Provavelmente nativa do Norte da América do Sul, é naturalizada e cultivada desde os Estados Unidos da América até a Argentina (Irwin \& Barneby 1982).

2. Senna aphylla (Cav.) H.S. Irwin \& Barneby, Mem. New York Bot. Gard. 35(2): 570. 1982.

Cassia aphylla Cav., Icon. 6: 41 t. 561. 1801.

Fig. 3.

Arbustos, eretos, $1 \mathrm{~m}$ alt., ramos glabros, exceto por alguns tricomas longos na base dos ramos. Estípulas ausentes. Folhas 1,3-1,6mm compr., reduzidas a 
Rodrigues, Flores, Miotto \& Baptista: O gênero Senna (Leguminosae, Caesalpinioideae) no Rio Grande do Sul...

escamas triangulares; pecíolo e glândulas ausentes. Racemos axilares, 1-3(-4) flores; pedúnculo 4-7,5mm compr.; brácteas linear-lanceoladas, $1-1,7 \mathrm{~mm}$ compr., caducas. Pedicelo 4,5-10mm compr. Sépalas 4,5-7,5mm compr.; corola assimétrica, amarela, pétalas $6,5-9 \mathrm{~mm}$ compr.; 4 estames medianos com filetes $0,9-1,2 \mathrm{~mm}$ compr. e anteras $3,8-4 \mathrm{~mm}$ compr., estames abaxiais com anteras isomórficas, estame centro-abaxial com filete $1,5-1,6 \mathrm{~mm}$ compr. e antera 4,8-5mm compr., 2 estames latero-abaxiais com filetes 1,7-2mm compr. e anteras 4,7-5,5mm compr., bico ausente; gineceu 7,5-8mm compr., ovário glabro. Legumes comprimidos, endocarpo seco, pêndulos, retos, glabros, $6,3-7,1 \times 0,5-0,6(-1,2) \mathrm{cm}$, sementes não vistas.

Material selecionado: BRASIL. Rio Grande do Sul: Porto Alegre, s.d., fl., Emrich s.n. (PACA 52485).

Espécie endêmica da Argentina (Bravo 1978; Fortunato 1999). É mencionada pela primeira vez para o Brasil, sendo somente encontrada sob cultivo como ornamental no Rio Grande do Sul.

3. Senna araucarietorum H.S. Irwin \& Barneby, Mem. New York Bot. Gard. 35(1): 370. 1982.

Fig. 4.

Arbustos ou arvoretas, eretos, 1,5-2m alt., ramos glabros. Estípulas linear-lanceoladas, $5-7 \mathrm{~mm}$ compr. Folhas 2-3(-4) pares de folíolos, 5-14cm compr.; pecíolo 2,8-6cm compr.; glândulas presentes entre os folíolos, ovóide-acuminadas, sésseis ou estipitadas, folíolos elípticos ou ovais, ápice acuminado ou raro agudo, base cuneada, folíolo distal $7-9 \times 2,1-3,2 \mathrm{~cm}$, com ambas as faces glabras. Racemos axilares, 2-15 flores; pedúnculo $25-45 \mathrm{~mm}$ compr.; brácteas lanceoladas, 3-5mm compr., caducas. Pedicelo 15-21 mm compr. Sépalas 5-11mm compr.; corola zigomorfa, amarela, pétalas $10-17 \mathrm{~mm}$ compr.; 4 estames medianos com filetes $2-3 \mathrm{~mm}$ compr. e anteras $4-5 \mathrm{~mm}$ compr., estames abaxiais com anteras isomórficas, estame centroabaxial com filete $4-5 \mathrm{~mm}$ compr. e antera $6-7 \mathrm{~mm}$ compr., 2 estames latero-abaxiais com filetes $9-10 \mathrm{~mm}$ compr. e anteras 7-8mm compr., bico ausente; gineceu 12-20mm compr., ovário glabro. Legumes cilíndricos, endocarpo seco, ascendentes, retos, glabros, $8,1-10,5 \times 0,5-0,7 \mathrm{~cm}$. Sementes 1 -seriadas, arredondadas, oliváceas ou castanho-escuras, $4-5 \times 4 \mathrm{~mm}$.

Material selecionado: BRASIL. Rio Grande do Sul: Bom Jesus, Serra da Rocinha, 18/XII/1969, fl., Ferreira \& Irgang s.n. (ICN 7441); Cambará do Sul, Itaimbezinho, 8/II/1983, fr., Jarenkow s.n. (ICN 66702); Caxias do Sul, 10/XII/1936, fr., Augusto s.n. (ICN 18559); Porto Alegre, 27/V/1944, fl., Emrich s.n.
(PACA 27428); Vacaria, Passo do Socorro, 26/XII/1951, fl., Rambo 51546 (PACA).

Ocorre na Argentina e Sul do Brasil (Irwin \& Barneby 1982). É citada pela primeira vez para o Rio Grande do Sul, onde habita borda de florestas com Araucaria. S. araucarietorum é muito similar morfologicamente com S. tropica (Vell.) H.S. Irwin \& Barneby e S. septemtrionalis (Viv.) H.S. Irwin \& Barneby. Segundo Irwin \& Barneby (1982), o orifício das duas anteras latero-abaxiais é obliquamente truncado e dirigido para o centro da flor em $S$. septemtrionalis, enquanto que em $S$. tropica e $S$. araucarietorum, o orifício está dirigido para fora do centro da flor. Além disso, em S. tropica, o ápice das anteras é proeminentemente 2-umbonado e em $S$. araucarietorum é horizontalmente truncado. O fruto tem valor diagnóstico para $S$. araucarietorum, por possuir uma série de sementes, enquanto que $S$. septemtrionalis e $S$. tropica apresentam duas séries. Ainda que neste trabalho estes táxons sejam considerados distintos, é necessária uma profunda revisão que confirme sua real separação.

4. Senna corymbosa (Lam.) H.S. Irwin \& Barneby, Mem. New York Bot. Gard. 35(1): 397. 1982.

Cassia corymbosa Lam., Encycl. 1(2): 644. 1785. Fig. 5-6.

Subarbustos, arbustos ou arvoretas, eretos, $0,5-3 \mathrm{~m}$ alt., ramos glabros. Estípulas lineares, 3-6mm compr. Folhas 2-3(-4) pares de folíolos, 6-14cm compr.; pecíolo 1,9-4,2cm compr.; glândulas presentes entre os folíolos do primeiro par, podendo aparecer entre os folíolos do segundo e terceiro pares, globosas, ovóides ou lanceolóides, estipitadas; folíolos ovais, ovallanceolados, elípticos ou oblongos, ápice agudo, obtuso ou retuso, mucronado ou não, base oblíqua ou obtusa, folíolo distal $2,1-7 \times 0,7-2,2 \mathrm{~cm}$, com ambas as faces glabras. Racemos axilares corimbiformes ou panículas terminais, 6-40 flores por racemo; pedúnculo $16-63 \mathrm{~mm}$ compr.; brácteas lineares ou linear-lanceoladas, 1,8-4mm compr., caducas. Pedicelo 14-25mm compr. Sépalas 5,5-12,5mm compr.; corola zigomorfa, amarela, pétalas 10-15mm compr; 4 estames medianos com filetes $2-3,4 \mathrm{~mm}$ compr. e anteras $4-6 \mathrm{~mm}$ compr., estames abaxiais com anteras isomórficas, estame centro-abaxial com filete $4-7,2 \mathrm{~mm}$ compr. e antera 6,6-8mm compr., 2 estames latero-abaxiais com filetes 6,5-12mm compr. e anteras $6,4-8 \mathrm{~mm}$ compr., bico 0,5-0,8mm compr.; gineceu 10-15mm compr., ovário glabro. Legumes cilíndricos, endocarpo pulposo, pêndulos, retos ou ligeiramente curvos, glabros, 
2,6-11,5×0,6-1,1cm. Sementes 1-seriadas, oblongas ou irregularmente ovais, negras, 4-5,5×3,2-4,8mm.

Material selecionado: BRASIL. Rio Grande do Sul: Alegrete, Reserva Biológica do Ibirapuitã, 21/III/1998 fl., Wasum s.n. (HUCS 12442); Bagé, 21/III/2001, fl., Flores \& Rodrigues 481 (ICN, UEC); Caçapava do Sul, 19/III/2000, fl., Rodrigues \& Flores 1044 (ICN); Camaquã, 23/III/2001, fl., Flores \& Rodrigues 499 (ICN); Cambará do Sul, 26/I/1948, fl., Rambo 36184 (ICN); Caxias do Sul, Vila Oliva, 1/IV/2000, fl. fr., Kegler 975 (HUCS); Erechim, 27/XII/1995, fr., Molon et al. s.n. (HUCS 11196); Ijuí, 8/IV/2000, fl., Rodrigues \& Flores 968 (ICN, UEC);
Osório, Lagoa da Pinguela, 8/V/1950, fl. fr., Rambo 47064 (PACA); Passo Fundo, IV/1957, fr., Freddiani s.n. (PACA 60746); Pelotas, 23/III/2001, fl., Rodrigues \& Flores 1063 (ICN, UEC); Porto Alegre, Morro do Osso, 3/VII/1995, fr., Rodrigues 07 (ICN, UEC); Quaraí, estância São Roberto, 17/IV/1976, fl. fr., Thomé s.n. (HAS 3805); Rosário do Sul, 20/III/2001, fl., Flores \& Rodrigues 472 (ICN); Santa Maria, 9/IV/2000, fl., Flores \& Rodrigues 392 (ICN, UEC); Santa Vitória do Palmar, Reserva Biológica do Taim, 11/VI/1986, fr., Mattos et al. 29478 (HAS); Santiago, 9/IV/2000, fl., Rodrigues \& Flores 977 (ICN); Torres, Parque de Torres, 11/VII/1972, fr., Baptista \& Lorscheitter s.n.

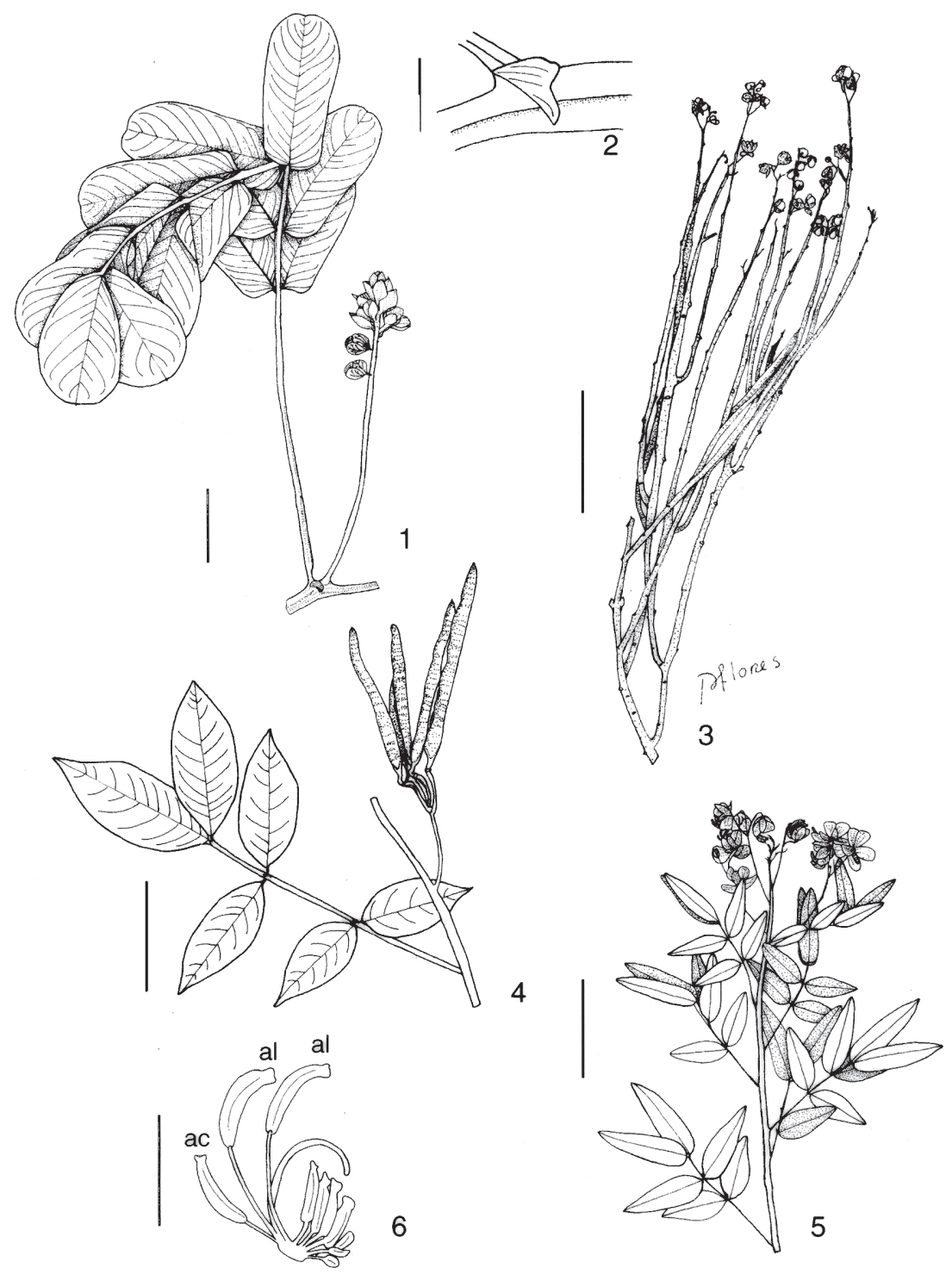

Figuras 1-6. 1-2. Senna alata (L.) Roxb. 1. Ramo com flores. 2. Estípula (Flores \& Rodrigues 462). 3. Senna aphylla (Cav.) H.S. Irwin \& Barneby); ramo com flores (Emrich s.n.). 4. Senna araucarietorum H.S. Irwin \& Barneby; ramo com frutos (Augusto s.n.). 5-6. Senna corymbosa (Lam.) H.S. Irwin \& Barneby. 5. Ramo com flores. 6. Androceu (Rodrigues \& Flores 977). (Abreviaturas: ac - estame centroabaxial; al - estames latero-abaxiais; escalas dos detalhes $1 \mathrm{~cm}$, hábitos $5 \mathrm{~cm}$ ). 
(ICN 28075); Uruguaiana, 3/IV/1977, fl., Porto et al. 2437 (ICN).

Conhecida como "sena, sena-do-mato, sene-docampo, fedegoso, café-brabo". É cultivada como ornamental e usada como medicinal (Dimitri \& Alberti 1954; Simões et al. 1995). Ocorre na Argentina, Paraguai, Uruguai e Brasil, também cultivada na Europa, naturalizada no Estados Unidos da América e subespontânea na África do Sul (Irwin \& Barneby 1982; Fortunato 1999). Cresce em campo úmido ou arenoso, em vegetação secundária e em borda de mata. Espécie amplamente distribuída em todas as regiões do Estado, sendo que algumas coleções podem apresentar maior número de flores que o mencionado por Irwin \& Barneby (1982), que citaram até 18 flores por racemo. $S$. corymbosa assemelha-se a $S$. pendula e $S$. hilariana, porém estas últimas possuem geralmente maior número de folíolos, estames abaxiais com anteras anisomórficas e sementes 2-seriadas.

5. Senna hilariana (Benth.) H.S. Irwin \& Barneby, Mem. New York Bot. Gard. 35(1): 396. 1982.

Cassia hilariana Benth, Martius, Fl. bras. 15(1): 108. 1870.

Fig. 7-9.

Arbustos, eretos ou apoiantes, $0,5-1,5 \mathrm{~m}$ alt., ramos glabros. Estípulas lineares ou linear-lanceoladas, 4-10mm compr. Folhas 4-9 pares de folíolos, $4-10 \mathrm{~cm}$ compr.; pecíolo 0,8-2,2cm compr.; glândulas presentes entre os folíolos do primeiro par (raro entre os do segundo par), ovóides ou lanceolóides, sésseis ou estipitadas; folíolos elípticos, oblongos, lineares, ovais ou oblanceolados, ápice agudo, mucronado, base oblíqua ou obtusa, folíolo distal 1,3-3×0,2-1 cm, ambas as faces glabras. Racemos axilares corimbiformes ou panículas terminais, 2-12 flores por racemo; pedúnculo 25-40mm compr.; brácteas lanceoladas ou linearlanceoladas, 3-7mm compr., persistentes ou caducas. Pedicelo 15-26mm compr. Sépalas 5-11mm compr.; corola zigomorfa, amarelo-ouro, pétalas $10-16 \mathrm{~mm}$ compr.; 4 estames medianos com filetes $1,2-2 \mathrm{~mm}$ compr. e anteras $3-5 \mathrm{~mm}$ compr., estames abaxiais com anteras anisomórficas, estame centro-abaxial com filete $2-3,3 \mathrm{~mm}$ compr. e antera $5-6 \mathrm{~mm}$ compr., 2 estames latero-abaxiais com filetes $5-8,5 \mathrm{~mm}$ compr. e anteras 6-8mm compr., bico $0,5-1 \mathrm{~mm}$ compr.; gineceu 10-14mm compr., ovário glabro. Legumes cilíndricos, endocarpo pulposo, pêndulos ou ascendentes, retos, glabros, 4-10,2×0,6-1,5cm. Sementes 2 -seriadas, oblongas ou irregularmente ovais, castanho-oliváceas, $4,5-6 \times 3,5-4,7 \mathrm{~mm}$.
Material selecionado: BRASIL. Rio Grande do Sul: Bossoroca, 12/I/1991, fl., Machado et al. 851 (SMDB); Canoas, São Luis, cultivada de sementes coletadas em São Luiz Gonzaga, 19/III/2000, fl. fr., Flores \& Rodrigues 402 (ICN); id., São Luis, 29/XII/2000, fr., Flores \& Rodrigues 439 (ICN); Roque González, 19/XII/2000, fl., Miotto 1887 (ICN, UEC); Santo Ângelo, 3/I/1979, fr., Longhi-Wagner et al. 871 (BLA); São Gabriel, 29/III/1991, fl., Machado et al. 1348 (SMDB); São Luiz Gonzaga, São Lourenço das Missões, 8/IV/2000, fr., Flores \& Rodrigues 387 (ICN); São Miguel das Missões, 10/XII/1976, fl., Miotto et al. 271 (ICN); Tupanciretã, Espinilho Grande, 11/I/1991, fl., Machado et al. 794 (SMDB).

Ocorre no Paraguai e Sul do Brasil (Irwin \& Barneby 1982). Cresce em áreas de campo limpo ou em formações arbustivas. Existiam dúvidas quanto ao número de séries de sementes e consistência do endocarpo em S. hilariana (Irwin \& Barneby 1982). Neste trabalho, descreve-se a morfologia de seus frutos, com endocarpo pulposo e duas séries de sementes e se ilustra pela primeira vez a espécie.

6. Senna hirsuta (L.) H.S. Irwin \& Barneby, Phytologia 44(7): 499. 1979.

Cassia hirsuta L., Sp. pl. 378. 1753. Fig. 10-11.

Cassia pubescens Jacq., Fragm. bot. 46, t. 57. 1809.

Cassia leptocarpa Benth., Linnaea 22: 528. 1849.

Arbustos, eretos, 1-1,5m alt., ramos pubescentes. Estípulas linear-lanceoladas, 3-8mm compr. Folhas 3-6 pares de folíolos, 7,5-19cm compr.; pecíolo 1,2-4,5cm compr.; glândulas presentes na base do pecíolo, ovóides ou globosas, sésseis; folíolos ovais, oval-lanceolados ou elípticos, ápice agudo, base cuneada ou oblíqua, folíolo distal 3,1-7×1,5-2,6cm, face adaxial pubescente e abaxial densamente pubescente. Racemos axilares e/ou panículas terminais, 5-25 flores por racemo; pedúnculo 5-30mm compr.; brácteas lineares ou ovallanceoladas, 1-2(-4)mm compr., caducas. Pedicelo 6-17mm compr. Sépalas 3-9mm compr.; corola zigomorfa, amarela, pétalas $8-13 \mathrm{~mm}$ compr.; 4 estames medianos com filetes $1-2 \mathrm{~mm}$ compr. e anteras $3-4 \mathrm{~mm}$ compr., estames abaxiais com anteras anisomórficas, estame centro-abaxial reduzido a estaminódio, com filete $2-4 \mathrm{~mm}$ compr. e antera $1,5-3 \mathrm{~mm}$ compr., 2 estames latero-abaxiais com filetes $3-6 \mathrm{~mm}$ compr. e anteras 4-6mm compr., bico 0,5-1 mm compr.; gineceu 11-12mm compr., ovário pubescente. Legumes comprimidos, endocarpo seco, ascendentes, curvos, 
torcidos 1-2 vezes em espiral, glabrescentes, $8-13 \times 0,3-0,6 \mathrm{~cm}$. Sementes 1 -seriadas, ovais, castanhas, $2-4 \times 2-3 \mathrm{~mm}$.

Material selecionado: BRASIL. Rio Grande do Sul: Alegrete, Restinga Seca, 28/I/1967, fr., Mattos \& Mattos 14691 (HAS); Caçapava do Sul, 19/III/2001, fl., Flores \& Rodrigues 469 (ICN, UEC); Entre-Ijuís, 8/IV/2000, fl. fr., Flores \& Rodrigues 384 (ICN, UEC); Esmeralda, 27/III/1979, fl. fr., Arzivenco s.n. (ICN 65532); Itaqui, 19/IV/1977, fl., Buselato 57 (HAS); Marcelino Ramos, 24/I/1995, fl., Butzke et al. s.n. (HUCS 11355); Passo Fundo, 26/I/1953, fl., Bertels s.n. (PEL 13024); Santa Maria, Itaimbé, 27/I/1936, fl., Rau \& Rambo s.n. (SMDB 173); Santiago, 20/XII/2000, fl., Miotto 1898 (ICN); Santo Ângelo, 18/II/1941, fl., Rambo 4658 (PACA); São Luiz Gonzaga, 19/XII/2000, fl., Miotto 1892 (ICN, UEC); São Miguel das Missões, 8/IV/2000, fl. fr., Rodrigues \& Flores 972 (ICN, UEC); Tapes, Bela Vista, 22/II/1985, fl. fr., Silveira et al. 2205 (HAS); Veranópolis, 21/V/2000, fl. fr., Ritter 1187 (ICN).

Popularmente conhecida como "fedegoso, lamperita”. Está amplamente distribuída na América, desde os Estados Unidos da América até a Argentina e Brasil (Irwin \& Barneby 1982). Cresce em campos arbustivos e em vegetação secundária. Espécie afim de $S$. neglecta, distinguindo-se pela forma dos folíolos e largura e forma dos frutos.

7. Senna leiophylla (Vogel) H.S. Irwin \& Barneby, Mem. New York Bot. Gard. 35(1): 248. 1982.

Cassia leiophylla Vogel, Gen. Cass. syn. 25. 1837 \& Linnaea 11: 672. 1837, descr. ampliat.

Subarbustos, eretos, até $0,7-1,5 \mathrm{~m}$ alt., ramos glabros. Estípulas lineares, 10-18mm compr. Folhas 2-3 pares de folíolos, 6-12cm compr.; pecíolo 0,6-1,6 (2,2)cm compr.; glândulas presentes entre os folíolos do primeiro par, oval-acuminadas, curtoestipitadas ou sésseis; folíolos obovados, oblanceolados ou elípticos, ápice ou agudo, mucronulado, base cuneada, folíolo distal 3,5-9×1,6-4cm, face adaxial glabra e abaxial glabrescente. Racemos axilares, 1-2 flores; pedúnculo 1-3mm compr.; brácteas oval-acuminadas, 2-3mm compr., caducas. Pedicelo 28-48mm compr. Sépalas $13-15 \mathrm{~mm}$ compr.; corola zigomorfa, pétalas 26-33mm compr.; 4 estames medianos com filetes $1-1,5 \mathrm{~mm}$ compr. e anteras 5,5-7,5mm compr., estames abaxiais com anteras isomórficas, estame centroabaxial com filete $5,5-9 \mathrm{~mm}$ compr. e antera $9-12 \mathrm{~mm}$ compr., 2 estames latero-abaxiais com filetes $5,5-9 \mathrm{~mm}$ compr. e anteras 9-12mm compr., bico 1,8-2mm compr.; gineceu com ovário pubescente. Legumes comprimidos, quadrangulares, endocarpo seco, ascendentes, curvos, glabros, $8-9 \times 0,4-0,5 \mathrm{~cm}$. Sementes não vistas.

Material selecionado: BRASIL. Rio Grande do Sul: Cachoeira do Sul, 20/V/1823, fl., Sellow s.n. (Foto F neg $1701 \mathrm{ICN})$.

Segundo Irwin \& Barneby (1982), S. leiophylla é uma espécie rara e local, que possui somente quatro coleções para o Paraguai, Argentina e Brasil, onde foi encontrada somente no Rio Grande do Sul. Esta espécie foi incluída neste estudo em razão da única coleção realizada no Estado ser o material tipo, feita por Sellow em 1823 e analisada através de fotografia. Senna leiophylla possivelmente está extinta no Rio Grande do Sul, visto que não foi novamente coletada. Dentre as espécies ocorrentes no Rio Grande do Sul, S. leiophylla é mais próxima de S. obtusifolia, por apresentar 2-3 pares de folíolos e pedúnculos de até $5 \mathrm{~mm}$ compr., porém distingue-se prontamente desta pelas pétalas maiores (26-33mm compr.). Neste trabalho, a descrição apresentada para S. leiophylla foi baseada na fotografia do tipo e em Irwin \& Barneby (1982).

8. Senna macranthera (Collad.) H.S. Irwin \& Barneby, Mem. New York Bot. Gard. 35(1): 181. 1982. Cassia macranthera Collad., Hist. nat. méd. Casses 99. 1816.

Cassia speciosa Schrad., Gött. Gel. Anz. 1:718. 1821.

Fig. 12.

Árvores ou arvoretas, eretas, 3-6m alt., ramos pubescentes ou glabrescentes. Estípulas linearlanceoladas, 7-10mm compr. Folhas 2 pares de folíolos, $12-23 \mathrm{~cm}$ compr.; pecíolo $2-5,2 \mathrm{~cm}$ compr.; glândulas presentes entre os folíolos do primeiro par, raro entre os folíolos do segundo par, ovóides, globosas ou fusiformes, sésseis ou estipitadas; folíolos obliquamente elíptico-lanceolados ou oval-lanceolados, ápice agudo ou curtamente acuminado, base oblíqua, folíolo distal $8,5-15,5 \times 2,5-5,5 \mathrm{~cm}$, face adaxial glabra e abaxial finamente pubescente. Racemos axilares e/ou panículas terminais, 7-20 flores por racemo; pedúnculo (8-)15-40mm compr.; brácteas oval-lanceoladas, 2-4mm compr., persistentes. Pedicelo 15-43mm compr. Sépalas 3-7mm compr.; corola zigomorfa, amarela, pétalas 17-32mm compr.; 4 estames medianos com filetes $1-4 \mathrm{~mm}$ compr. e anteras $5-9 \mathrm{~mm}$ compr., estames abaxiais com anteras isomórficas, estame centroabaxial com filete $2-4 \mathrm{~mm}$ compr. e antera $8-11 \mathrm{~mm}$ compr., 2 estames latero-abaxiais com filetes $2-5 \mathrm{~mm}$ 
compr. e anteras $7-12 \mathrm{~mm}$ compr., bico $1,2-1,7 \mathrm{~mm}$ compr.; gineceu 17-25mm compr., ovário pubescente. Legumes cilíndricos, endocarpo seco, pêndulos, retos, glabros, 15,5-21×1,4-2cm. Sementes 2-seriadas, obcordiformes, castanho-escuras, brilhantes, 7-8×5,8-6,5mm.

Material selecionado: BRASIL. Rio Grande do Sul: Canoas, São Luis, 18/V/2000, fl., Rodrigues \& Flores 988 (ICN); id, São Luis, 11/I/2001, fl., Flores \& Rodrigues 441 (ICN); Caxias do Sul, Campus da UCS, 12/II/1993, fl., Molon et al. s.n. (HUCS 8965); Giruá, 19/XII/2000, fl., Miotto 1885 (ICN); Pelotas, Horto Florestal, 8/IV/1964, fl., Kappel s.n. (BLA 4091); Rio Grande, Parque Universitário Rio Grande, 18/IV/1986, fl., Perazzolo s.n. (HURG 2577); Santa Maria, Campus da UFSM, 23/III/1993, fl., CantoDorow s.n. (SMDB 4021).

Vulgarmente conhecida como "manduirana, bolãode-ouro, chuva-de-ouro, fedegoso, pau-de-ovelha".
Cultivada como ornamental e tem sua madeira empregada na carpintaria e como lenha (Lorenzi 1992). Ocorre na Venezuela, Equador, Peru e no Brasil desde o Piauí até São Paulo (Irwin \& Barneby 1982), sendo cultivada de São Paulo até Rio Grande do Sul. No Rio Grande do Sul se encontra cultivada ou espontânea em bordas de mata.

9. Senna multijuga (Rich.) H.S. Irwin \& Barneby, Mem. New York Bot. Gard. 35(2): 492. 1982.

Cassia multijuga Rich., Actes Soc. Hist. Nat. Paris 1: 108. 1792.

Fig. 13-14.

Arbustos ou arvoretas, eretos, $2-5 \mathrm{~m}$ alt., ramos glabros ou pubérulos. Estípulas filiformes, 4-12mm compr. Folhas 9-23 pares de folíolos, 6-27cm compr.; pecíolo 1,2-2,5cm compr.; glândulas presentes entre os folíolos do primeiro par e entre os folíolos dos pares

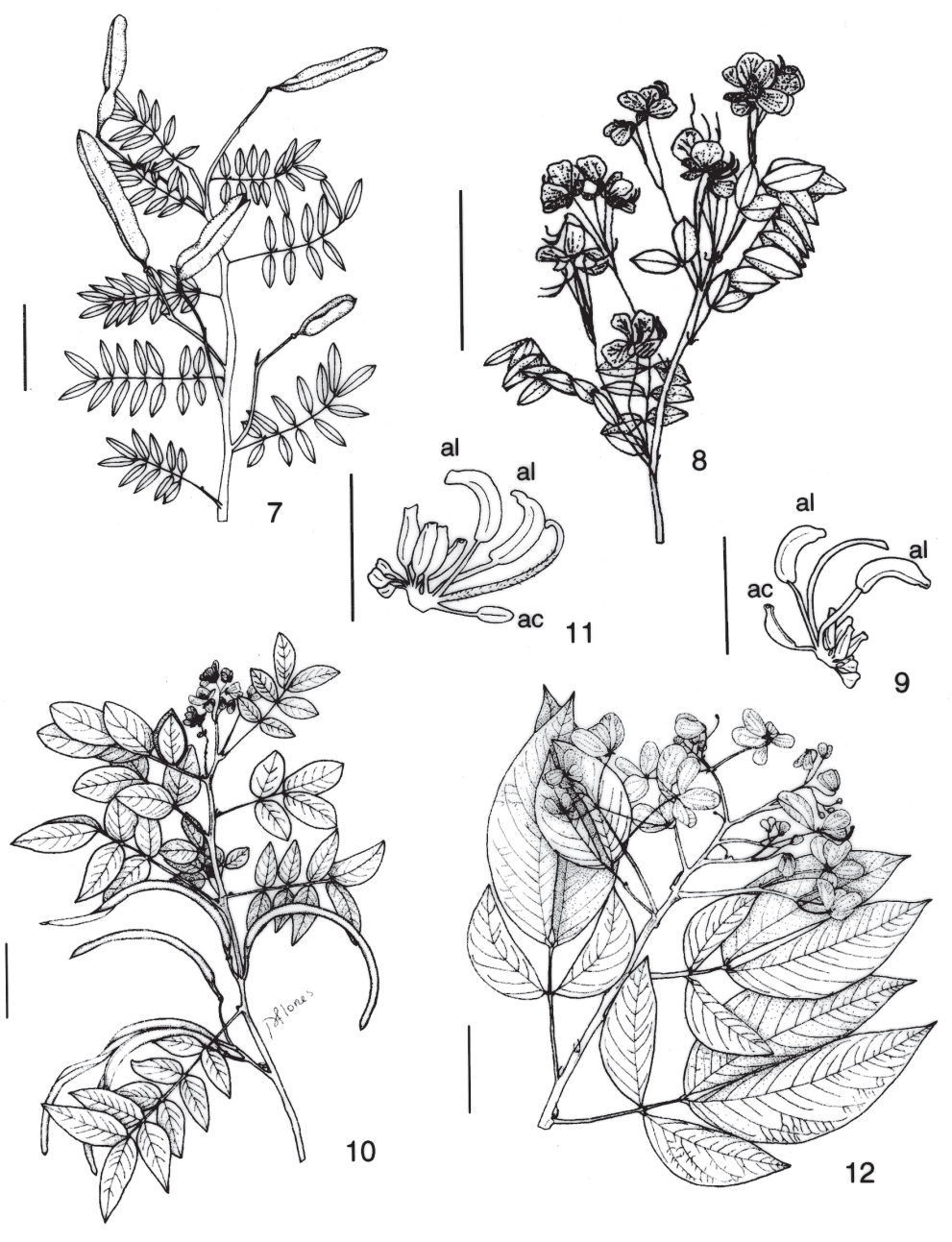

Figuras 7-12. 7-9. Senna hilariana (Benth.) H.S. Irwin \& Barneby. 7. Ramo com frutos (Flores \& Rodrigues 439). 8. Ramo com flores. 9. Androceu (Flores \& Rodrigues 402). 10-11. Senna hirsuta (L.) H.S. Irwin \& Barneby. 10. Ramo com flores e frutos (Ritter 1187). 11. Androceu (Miotto 1892). 12. Senna macranthera (Collad.) H.S. Irwin \& Barneby; ramo com flores (Flores \& Rodrigues 441). (Abreviaturas: ac - estame centro-abaxial; al - estames latero-abaxiais; escalas dos detalhes $1 \mathrm{~cm}$, hábitos $5 \mathrm{~cm}$ ). 
distais, ovóides, lanceolóides ou fusiformes, sésseis ou estipitadas; folíolos oblongos, oblongo-elípticos ou oblanceolados, ápice truncado, arredondado, obtuso ou retuso, mucronado, base oblíqua ou cuneada, folíolo distal 9-34×3-10cm, com ambas as faces pubérulas ou glabrescentes. Racemos axilares ou panículas terminais, 4-37 flores por racemo; pedúnculo 14-40 mm compr.; brácteas lanceoladas ou linear-lanceoladas, 1,6-3mm compr., caducas. Pedicelo 15-28mm compr. Sépalas 3-6,5mm compr.; corola assimétrica, amareloouro, pétalas 11-20mm compr.; 4 estames medianos com filetes $1,2-2,5 \mathrm{~mm}$ compr. e anteras $3,5-6 \mathrm{~mm}$ compr., estames abaxiais com anteras isomórficas, estame centro-abaxial com filete $2-3 \mathrm{~mm}$ compr. e antera $6-8 \mathrm{~mm}$ compr., 2 estames latero-abaxiais com filetes $3,2-5,6 \mathrm{~mm}$ compr. e anteras $7-11 \mathrm{~mm}$ compr., bico curvo, 1,7-2,5mm compr.; gineceu 12,5-19mm compr., ovário pubescente. Legumes comprimidos, endocarpo seco, pêndulos, retos, margens sinuosas, glabros, (4,5-)8-13×1-2,2cm. Sementes 1-seriadas, oblongas ou oblanceoladas, castanho-escuras, $5-7 \times 1,5-2,1 \mathrm{~mm}$.

Material selecionado: BRASIL. Rio Grande do Sul: Canoas, Igara, 16/IV/2000, fl. fr., Rodrigues \& Flores 986 (ICN); Pantano Grande, 19/III/2001, fl., Rodrigues \& Flores 1042 (ICN, UEC); Passo Fundo, 26/II/1975, fl. fr., Arzivenco s.n. (ICN 67742); Pelotas, 23/III/2001, fl., Rodrigues \& Flores 1064 (ICN, UEC); Porto Alegre, Tristeza, 17/I/2001, fl., Rodrigues \& Flores 1038 (ICN, UEC); Santa Maria, Jardim Botânico-UFSM, 2/IV/1987, fl. fr., Villanova s.n. (SMDB 2702); Taquari, 28/XII/1978, fl., Hiltt s.n. (MPUC 7941a).

Conhecida como "chuva-de-ouro, bolão-de-ouro, aleluia, cássia”. Originária da América do Sul, amplamente cultivada nos trópicos. No Brasil é nativa até Santa Catarina (Irwin \& Barneby 1982). No Rio Grande do Sul é cultivada ou espontânea em borda de mata.

10. Senna nana (Benth.) H.S. Irwin \& Barneby, Mem. New York Bot. Gard. 35(1): 290. 1982.

Cassia nana Benth., Martius, Fl. bras. 15(1): 110. 1870.

Fig. 15.

Subarbustos, eretos, $3-15 \mathrm{~cm}$ alt., ramos finamente pubescentes. Estípulas linear-lanceoladas, 2-5,4mm compr. Folhas 1(-2) pares de folíolos, 2,3-6,3cm compr.; pecíolo 1-3,1 cm compr.; glândulas presentes entre os folíolos do primeiro par, depresso-ovóides, sésseis; folíolos ovais ou elípticos, ápice obtuso, agudo ou arredondado, base oblíqua, folíolo distal $1,3-4 \times 1,1-2,5 \mathrm{~cm}$, face adaxial glabra e abaxial pubescente ou glabrescente. Racemos axilares com 1 flor; pedúnculo 3-10mm compr.; brácteas não vistas. Pedicelo 35-40mm compr. Sépalas 5-6mm compr.; corola zigomorfa, amarela, pétalas $10-13 \mathrm{~mm}$ compr.; 4 estames medianos com filetes $1,5-2 \mathrm{~mm}$ compr. e anteras $3 \mathrm{~mm}$ compr., estames abaxiais com anteras anisomórficas, estame centro-abaxial reduzido a estaminódio com filete $3 \mathrm{~mm}$ compr. e antera $3-3,5 \mathrm{~mm}$ compr., 2 estames latero-abaxiais com filetes $4 \mathrm{~mm}$ compr. e anteras 4-5mm compr., bico ausente; gineceu $8 \mathrm{~mm}$ compr., ovário pubescente. Legumes cilíndricos, pouco comprimidos, endocarpo seco, ascendentes, ligeiramente curvos, glabrescentes, $2,5-6 \times 0,5-0,7 \mathrm{~cm}$. Sementes 1-seriadas, ovais, castanho-escuras, $3,9-5 \times 2,8-3,5 \mathrm{~mm}$.

Material selecionado: BRASIL. Rio Grande do Sul: Alegrete, arroio Lageadinho, 21/XII/1981, fr., Sobral \& Stehmann 918 (ICN); id., 14/III/2002, fl., Knob \& Bordignon 7089 (UNILASALLE); Lavras do Sul, 30/III/1991, fr., Machado 1425 (SMDB); Quaraí, Fazenda do Jarau, I/1945, fr., Rambo 26141 (PACA); Santana do Livramento, Caverá, 29/XI/1987, fr., Machado 14B (SMDB).

Ocorre no Uruguai, Argentina e Brasil, somente no Rio Grande do Sul (Rambo 1966; Irwin \& Barneby 1982; Mattos 1983). No Estado, cresce em áreas de campo limpo. Anteriormente a este trabalho, a morfologia dos frutos e sementes desta espécie era pouco conhecida, especialmente quanto ao número de séries de sementes e consistência do endocarpo (Irwin \& Barneby 1982).

11. Senna neglecta (Vogel) H.S. Irwin \& Barneby, Mem. New York Bot. Gard. 35(1): 421. 1982.

Cassia neglecta Vogel, Linnaea 10(5): 594. 1836. Fig. 16.

Arbustos ou arvoretas, eretos $1-4 \mathrm{~m}$ alt., ramos pubescentes. Estípulas linear-lanceoladas, 4-6mm compr. Folhas (2-)3-6 pares de folíolos, 7-18,5cm compr.; pecíolo 1,7-4,2cm compr.; glândulas presentes na base do pecíolo, raramente também entre os folíolos do primeiro par, ovóides, globosas ou cônicas, sésseis; folíolos oblanceolados, obtrulados, oblongo-elípticos ou elípticos, ápice agudo ou obtuso, base oblíqua ou obtusa, folíolo distal 3-9,5×1-3cm, face adaxial glabrescente ou finamente pubescente e abaxial pubescente. Racemos axilares e/ou panículas terminais, 5-27 flores por racemo; pedúnculo $10-26 \mathrm{~mm}$ compr.; brácteas lineares ou linear-lanceoladas, 1,5-4mm compr., 
caducas. Pedicelo 10-17mm compr. Sépalas 6-12mm compr.; corola zigomorfa, amarela, pétalas $9-16 \mathrm{~mm}$ compr.; 4 estames medianos com filetes $1,5-2,5 \mathrm{~mm}$ compr. e anteras $3,5-5 \mathrm{~mm}$ compr., estames abaxiais com anteras anisomórficas, estame centro-abaxial reduzido a estaminódio com filete $2,5-6 \mathrm{~mm}$ compr. e antera $2-4,5 \mathrm{~mm}$ compr., 2 estames latero-abaxiais com filetes $5-8 \mathrm{~mm}$ compr. e anteras $5-7 \mathrm{~mm}$ compr., bico 0,7-1 mm compr.; gineceu 9-16mm compr., ovário pubescente. Legumes comprimidos, endocarpo seco, pêndulos, retos ou curvos, glabrescentes, $6,5-16,5 \times 0,8-1,2 \mathrm{~cm}$. Sementes 1-seriadas, oblongas, castanho-oliváceas, 4,4-6×2-3mm.

Material selecionado: BRASIL. Rio Grande do Sul: Bom Jesus, 15/I/2001, fl., Flores \& Rodrigues 458 (ICN, UEC); Cambará do Sul, 25/I/1948, fl., Rambo 36185 (ICN); Fontoura Xavier, Vila Assis, 7/IV/2000, fr., Flores \& Rodrigues 381 (ICN, UEC); Guaíba, 23/III/2001, fl., Flores \& Rodrigues 502 (ICN, UEC); Jaquirana, 19/IV/2000, fl. fr., Flores \& Rodrigues 395 (ICN); Osório, Serra do Pinto, 30/III/1989, fl. fr., Silveira 8647 (HAS); Paim Filho, 29/XII/1997, fl. fr., Jarenkow 3725 (PEL); Pelotas, 22/V/1959, fl. fr., Sacco 1252 (PEL); São Francisco de Paula, 25/III/1981, fl., Mattos \& Mattos 22656 (HAS); Tapes, 23/III/2001, fl., Rodrigues \& Flores 1066 (ICN, UEC); Taquara, 11/IV/2000, fl., Ritter 1146 (ICN, UEC); Torres, Rio Terra, 31/III/1989, fl., Silveira 8504 (HAS); Vacaria, 20/IV/2000, fr., Flores \& Rodrigues 396 (ICN, UEC).

Ocorre no Sul, Sudeste e Nordeste do Brasil (Irwin $\&$ Barneby 1982). Cresce em campo, em vegetação secundária, em borda e interior de mata.

12. Senna oblongifolia (Vogel) H.S. Irwin \& Barneby, Mem. New York Bot. Gard. 35(1): 374. 1982. Cassia oblongifolia Vogel, Gen. Cass. syn. 23. 1837 \& Linnaea 11: 666. 1837, descr. ampliat.

Fig. 17-18.

Arbustos, arvoretas ou árvores, eretos, 1-10m alt., ramos glabros ou densamente pubescentes. Estípulas linear-lanceoladas, $4-13 \mathrm{~mm}$ compr. Folhas (3-)4-9(-10) pares de folíolos, 6-23,5cm compr.; pecíolo 1,7-6,5cm compr.; glândulas presentes no pecíolo, às vezes entre os folíolos do primeiro par ou entre os folíolos dos pares distais, ovóides, fusiformes, sésseis ou estipitadas; folíolos oblongos, oblongoelípticos ou raramente oblanceolados, ápice obtuso, retuso, arredondado ou agudo, base oblíqua, cuneada ou obtusa, folíolo distal 2-6,6×0,8-1,8cm, face adaxial glabra, raramente pubérula e abaxial glabra, com tricomas canescentes na base ou densamente pubescentes. Racemos axilares ou panículas terminais, 4-30 flores por racemo; pedúnculo $15-58 \mathrm{~mm}$ compr.; brácteas linear-lanceoladas, $2-9 \mathrm{~mm}$ compr., caducas. Pedicelo 15-35mm compr. Sépalas 3,5-9mm compr.; corola zigomorfa, amarela, pétalas 8-16mm compr.; 4 estames medianos com filetes $1-4,5 \mathrm{~mm}$ compr. e anteras $3-5 \mathrm{~mm}$ compr., estames abaxiais com anteras isomórficas, estame centroabaxial com filetes $2-5,5 \mathrm{~mm}$ compr. e antera $4-6 \mathrm{~mm}$ compr., 2 estames latero-abaxiais com filetes 3-7,7mm compr. e anteras $4-7 \mathrm{~mm}$ compr., bico 0,4-0,5mm compr.; gineceu 8-14mm compr., ovário pubescente. Legumes cilíndricos, ligeiramente comprimidos, endocarpo seco, ascendentes, curvos, glabros, 4-10×0,6-0,9cm. Sementes 1-seriadas, orbiculares, castanho-escuras, $4-5 \times 4-5 \mathrm{~mm}$.

Material selecionado: BRASIL. Rio Grande do Sul: Bom Jesus, 15/I/2001, fl. fr., Flores \& Rodrigues 457 (ICN); Cambará do Sul, 14/I/2001, fl., Rodrigues \& Flores 1032 (ICN, UEC); Dois Irmãos, 27/XII/1983, fl. fr., Abruzzi 859 (HAS); Jaquirana, 15/I/2001, fl., Rodrigues \& Flores 1036 (ICN); Planalto, Reserva Florestal de Planalto, 7/XII/1974, fl. fr., Baptista et al. s.n. (HAS 83057, ICN 26825); Porto Alegre, Morro do Osso, 20/XI/1993, fl. fr., Brack 354 (HAS); São Salvador, 10/XI/1949, fl., Sehnen 4014 (HUCS, PACA); Soledade, 12/XI/1975, fr., Hagelund 9751 (ICN).

Ocorre na Argentina, Uruguai, Sul e Sudeste do Brasil (Irwin \& Barneby 1982; Fortunato 1999). Cresce em campo arbustivo, vegetação secundária, borda e interior de matas com Araucaria. Esta espécie é muito variável no hábito, pubescência e número de folíolos, podendo ser encontrada populações com (3-)4-5 folíolos e outras com 6-9(-10) folíolos. As glândulas de S. oblongifolia são encontradas sempre no pecíolo e, algumas vezes, também entre os folíolos dos pares proximais, confirmando observações de Irwin \& Barneby (1982). Entretanto, glândulas foram encontradas entre os pares de folíolos distais de duas coleções (Flores \& Rodrigues 454 e Rodrigues \& Flores 1032). S. oblongifolia se diferencia das outras espécies com glândulas presentes no pecíolo ocorrentes no Rio Grande do Sul por apresentar estames centroabaxais não reduzidos a estaminódios, pedicelos geralmente maiores e folíolos predominantemente oblongos a oblongo-elípticos.

13. Senna obtusifolia (L.) H.S. Irwin \& Barneby, Mem. New York Bot. Gard. 35(1): 252. 1982.

Cassia obtusifolia L., Sp. pl. 377. 1753.

Fig. 19. 
Subarbustos ou arbustos, eretos, até $1 \mathrm{~m}$ alt., ramos glabrescentes. Estípulas lineares ou subuladas, $5-15 \mathrm{~mm}$ compr. Folhas 2-3 pares de folíolos, 6,5-14cm compr.; pecíolo 1,5-5cm compr.; glândulas presentes entre os folíolos do primeiro par, algumas vezes também entre os folíolos do segundo par, fusiformes, curto-estipitadas ou sésseis; folíolos obovados, oblongo-elípticos ou suborbiculares, ápice retuso, arredondado, mucronulado ou agudo, base oblíqua ou cuneada, folíolo distal $3,3-5,8 \times 1,8-3 \mathrm{~cm}$, face adaxial glabra e abaxial finamente pubescente. Racemos axilares, 1-3(-4) flores; pedúnculo $1-5 \mathrm{~mm}$ compr.; brácteas linear-lanceoladas, 2-4mm compr., persistentes ou tardiamente caducas. Pedicelo 9-25mm compr. Sépalas 4-7mm compr.; corola zigomorfa, alaranjada, pétalas 7-12mm compr.; 4 estames medianos com filetes $1,5-2 \mathrm{~mm}$ compr. e anteras $2-3 \mathrm{~mm}$ compr., estames abaxiais com anteras isomórficas, estame centro-abaxial com filete $1-2 \mathrm{~mm}$ compr. e antera 3-3,5mm compr., 2 estames lateroabaxiais com filetes $2-3 \mathrm{~mm}$ compr. e anteras $3-4 \mathrm{~mm}$ compr., bico $0,3-0,8 \mathrm{~mm}$ compr.; gineceu $8-15 \mathrm{~mm}$ compr., ovário pubescente. Legumes comprimidos, quadrangulares, endocarpo seco, ascendentes, curvos, glabros, $7,5-15 \times 0,4-0,5 \mathrm{~cm}$. Sementes 1 -seriadas, irregularmente rômbicas, castanhas, $4-5 \times 2-3 \mathrm{~mm}$.

Material selecionado: BRASIL. Rio Grande do Sul: Bossoroca, 9/IV/2000, fl., Flores \& Rodrigues 388 (ICN, UEC); Canoas, São Luis, 11/V/2000, fl., Flores \& Rodrigues 403 (ICN, UEC); Coronel Barros, 8/IV/2000, f1. fr., Rodrigues \& Flores 970 (ICN, UEC); Porto Alegre, Faculdade de Veterinária, V/1976, fl. fr., Martins s.n. (HAS 83045); Santana do Livramento, 20/III/2001, fl., Flores \& Rodrigues 477 (ICN); Santiago, 9/IV/2000, fl., Flores \& Rodrigues 390 (ICN); Santo Antônio das Missões, 19/XII/2000, fl., Miotto 1896 (ICN); São Miguel das Missões, 8/IV/2000, fl., Flores \& Rodrigues 385 (ICN, UEC); São Borja, 12/II/1974, fl., Hagelund 7967 (ICN). São Pedro do Sul, 9/IV/2000, fl. fr., Rodrigues \& Flores 979 (ICN).

Espécie provavelmente originária da América, amplamente distribuída desde os Estados Unidos da América até a Argentina e Brasil, sendo encontrada também em regiões tropicais da Ásia e África (Irwin \& Barneby 1982). No Estado ocorre em vegetacão secundária, como invasora de culturas e em borda de mata.

14. Senna occidentalis (L.) Link, Handbuch 2: 140. 1831. Cassia occidentalis L., Sp. pl. 377. 1753.

Fig. 20.
Subarbustos ou arbustos, eretos, 0,3-2m alt., ramos glabros ou glabrescentes. Estípulas triangulares, 3-6mm compr. Folhas 3-6-pares de folíolos, 9-23cm compr.; pecíolo (1,5-)1,7-4,5cm compr.; glândulas presentes na base do pecíolo, ovóides ou globosas, sésseis; folíolos elípticos ou oval-lanceolados, ápice agudo ou acuminado, base oblíqua, folíolo distal 5-8,1×1,7-3,3cm, face adaxial glabra e abaxial glabra até finamente papilosa. Racemos axilares, 2-4(-5) flores; pedúnculo 2-6mm compr.; brácteas lanceoladas, 8-13mm compr., caducas. Pedicelo 6-15mm compr. Sépalas 6-10mm compr.; corola zigomorfa, amarelo-pálida, pétalas $10-16 \mathrm{~mm}$ compr.; 4 estames medianos com filetes $2-3 \mathrm{~mm}$ compr. e anteras $4-5 \mathrm{~mm}$ compr., estames abaxiais com anteras anisomórficas, estame centroabaxial reduzido a estaminódio com filete $3-5 \mathrm{~mm}$ compr. e antera $2-3 \mathrm{~mm}$ compr., 2 estames lateroabaxiais com filetes $4-8 \mathrm{~mm}$ compr. e anteras $5-6 \mathrm{~mm}$ compr., bico 1,5-2mm compr.; gineceu 10-16mm compr., ovário pubescente. Legumes comprimidos, endocarpo seco, ascendentes, ligeramente curvos, glabros ou pubérulos, $11-13,5 \times 0,7-1 \mathrm{~cm}$. Sementes 1 -seriadas, ovais, oliváceas, $3-5 \times 2-4 \mathrm{~mm}$.

Material selecionado: BRASIL. Rio Grande do Sul: Agudo, Nova Boêmia, 23/III/1981, fr., A. Filho et al. s.n. (SMDB 1963); Cachoeira do Sul, mina Iruí, IV/1985, fl. fr., Sobral 3849 (ICN); Canoas, São Luis, 5/V/2000, fl. fr., Flores \& Rodrigues 400 (ICN); Coronel Barros, 8/IV/2000, fl. fr., Rodrigues \& Flores 969 (ICN); Estrela, 10/V/1985, fr., Miotto 1032 (ICN); Porto Alegre, Belém Novo, 22/III/1986, fl. fr., Brack s.n. (ICN 66463); Rio Grande, 22/III/2001, fl., Rodrigues \& Flores 1059 (ICN); Santa Maria, Santa Flora, 28/III/1991, fl. fr., Machado et al. 1288 (SMDB); São Borja, 14/I/1991, fl. fr., Machado et al. 1023 (SMDB); São Gabriel, 19/III/2001, fl., Rodrigues \& Flores 1047 (ICN); Tenente Portela, Parque Estadual Florestal do Turvo, 9/VII/1980, fl., Irgang s.n. (ICN 47759); São Borja, 12/II/1974, fl., Hagelund 7968 (ICN).

Conhecida como" fedegoso", suas sementes são tostadas e empregadas como sucedâneos do café e têm aplicações medicinais como febrífugas (Burkart 1987). Além disso, os ramos e folhas são utilizados para se fazer tinta (Dimitri \& Alberti 1954). Espécie paleotropical, provavelmente introduzida no continente americano (Irwin \& Barneby 1982). Entretanto, segundo Reveal (1991), S. occidentalis é uma espécie nativa nos neotrópicos. No Estado, cresce em campo arenoso, em vegetação secundária e borda de mata, sendo também invasora de culturas. 
15. Senna pendula (Willd.) H.S. Irwin \& Barneby, Mem. New York Bot. Gard. 35(1): 378. 1982.

Cassia pendula Willd., Enum. pl. 1. 440. 1809.

Fig. 21.

Arbustos ou arvoretas, eretos, 2-3m alt., ramos glabros ou pubérulos. Estípulas linear-lanceoladas, 2-11 mm compr. Folhas (3-)4-6 pares de folíolos, 4,5-13cm compr.; pecíolo 1,3-4,3cm compr.; glândulas presentes entre os folíolos do primeiro par, raro entre os folíolos do segundo par, ovóides ou globosas, sésseis ou estipitadas; folíolos elípticos, oblongos, obovados ou oblanceolados, ápice arredondado, obtuso ou retuso, base oblíqua, folíolo distal 2-4,6×1-2,2cm, faces adaxial glabra e abaxial com tricomas canescentes próximos à base. Racemos axilares ou panículas terminais, (2-)5-22 flores por racemo; pedúnculo $17-52 \mathrm{~mm}$ compr.; brácteas linear-lanceoladas, (1-)2,6-4,5mm compr., caducas. Pedicelo 10-28mm compr. Sépalas 6,5-15mm compr.; corola zigomorfa, amarelo-ouro, pétalas $13-23 \mathrm{~mm}$ compr.; 4 estames medianos com filetes $1,6-2,7 \mathrm{~mm}$ compr. e anteras $5-7,3 \mathrm{~mm}$ compr., estames abaxiais com anteras anisomórficas, estame centro-abaxial com filetes $5-8 \mathrm{~mm}$ compr. e antera 6,5-10mm compr., 2 estames latero-abaxiais com filetes $14-24 \mathrm{~mm}$ compr. e anteras $7,5-11 \mathrm{~mm}$ compr., bico 0,7-1,4mm compr.; gineceu 20-32mm compr., ovário ligeramente pubescente ou glabro. Legumes cilíndricos, endocarpo pulposo, pêndulos, retos, glabros, 14,6-19,5×1-1,2cm. Sementes 2 -seriadas, oblongoelípticas, negras, 4,5-7×3,4-4,4mm.

Material selecionado: BRASIL. Rio Grande do Sul: Canoas, São José, 5/V/2000, fl., Flores \&
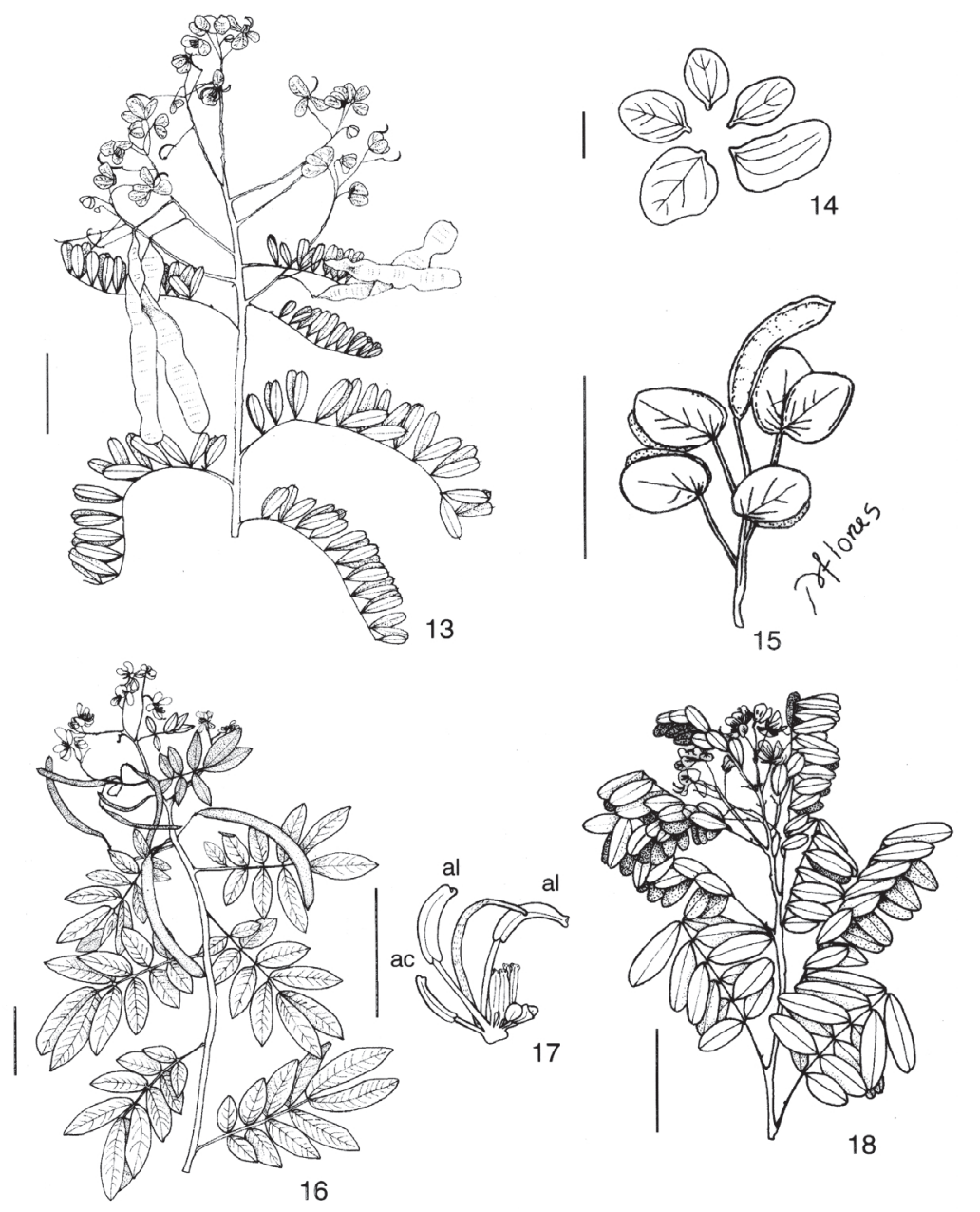

Figuras 13-18. 13-14. Senna multijuga (Rich.) H.S. Irwin \& Barneby. 13. Ramo com flores e frutos. 14. Pétalas (Rodrigues \& Flores 980 ). 15. Senna nana (Benth.) H.S. Irwin \& Barneby; hábito (Sobral \& Stehmann 918). 16. Senna neglecta (Vogel) H.S. Irwin \& Barneby; ramo com flores e frutos (Flores \& Rodrigues 395). 17-18. Senna oblongifolia (Vogel) H.S. Irwin \& Barneby. 17. Androceu. 18. Ramo com flores (Rodrigues \& Flores 1036). (Abreviaturas: ac - estame centro-abaxial; al - estames latero-abaxiais; escalas dos detalhes $1 \mathrm{~cm}$, hábitos $5 \mathrm{~cm})$. 
Rodrigues 399 (ICN, UEC); Coronel Barros, 8/IV/2000, fl., Flores \& Rodrigues 382 (ICN, UEC); Igrejinha, 19/IV/2000, fl., Rodrigues \& Flores 980 (ICN, UEC); Nova Petrópolis, Linha Imperial, 21/IV/2000, fl., Ritter 1157 (ICN, UEC); Porto Alegre, 3/V/1986, fl., Etchler s.n. (HAS 83058); São Marcos, 20/IV/2000, fl., Rodrigues \& Flores 985 (ICN, UEC); São Miguel das Missões, 30/IV/1982, fl., Irgang s.n. (ICN 51759); Uruguaiana, 24/IV/1985, fl., Galvani 582 (HUCS); Vila Maria, 2/VI/2000, fl., Ritter 1192 (ICN, UEC).

Conhecida como "canudo-de-pito, fedegoso". Originária desde o México até a Argentina. Espécie amplamente distribuída no Brasil (Irwin \& Barneby 1982). É mencionada pela primeira vez para o Estado. Cresce em vegetação secundária, sendo também cultivada como ornamental. Tradicionalmente confundida com S. bicapsularis (L.) Roxburgh., diferenciando-se por seus pedicelos de maior tamanho. S. bicapsularis não teve sua presença confirmada no Rio Grande do Sul.

16. Senna pilifera (Vogel) H.S. Irwin \& Barneby, Mem. New York Bot. Gard. 35(1): 241. 1982.

Cassia pilifera Vogel, Gen. Cass. syn. 23. 1837. Fig. 22.

Subarbustos, prostrados ou decumbentes, $0,3-0,8 \mathrm{~m}$ compr., ramos pubescentes. Estípulas linearlanceoladas ou subuladas, $5-16 \mathrm{~mm}$ compr. Folhas sempre com 2 pares de folíolos, 5,5-9,5(-12)cm compr.; pecíolo 1,8-4cm compr.; glândulas presentes entre os folíolos, ovóides ou fusiformes, estipitadas; folíolos obovados, elípticos ou orbiculares, ápice retuso, agudo ou arredondado, base subcordada ou oblíqua, folíolo distal $3-6,7 \times 2,2-4,3 \mathrm{~cm}$, ambas as faces finamente pubescentes ou glabrescentes. Racemos axilares, 2-3 flores; pedúnculo 2,2-10cm compr.; brácteas lanceoladas, 3-5 $\mathrm{mm}$ compr., persistentes ou tardiamente caducas. Pedicelo 1,5-3cm compr. Sépalas 9-11 mm compr.; corola zigomorfa, alaranjada, pétalas 20-32mm compr.; 4 estames medianos com filetes 1-3mm compr. e anteras $5-9 \mathrm{~mm}$ compr., estames abaxiais com anteras isomórficas, estame centroabaxial com filete $3-6 \mathrm{~mm}$ compr. e antera $10-14 \mathrm{~mm}$ compr., 2 estames latero-abaxiais com filetes $4-7 \mathrm{~mm}$ compr. e anteras $10-14 \mathrm{~mm}$ compr., bico $0,9-1 \mathrm{~mm}$ compr.; gineceu 20-30mm compr., ovário pubescente. Legumes comprimidos, endocarpo seco, ascendentes, retos ou curvos, às vezes ligeiramente torcidos em espiral, pubérulos ou glabrescentes, $16-24,5 \times 0,3-0,8 \mathrm{~cm}$. Sementes 1-seriadas, oblongas, castanho-escuras, brilhantes, $4-6 \times 2-3 \mathrm{~mm}$.
Material selecionado: BRASIL. Rio Grande do Sul: Alegrete, Tigre, 23/XII/1958, fl. fr., Mattos 6354 (HAS); Bossoroca, 9/IV/2000, fr., Flores \& Rodrigues 389 (ICN); Cruz Alta, 2/II/1971, fl. fr., Porto \& Oliveira s.n. (HAS 4948, ICN 9635); Roque González, 19/XII/2000, fl., Miotto 1888 (ICN); Santiago, Assentamento Santa Rita, 04/II/1989, fl. fr., Machado et al. 191 (SMDB); Santo Ângelo, Granja Piratini, 9/XII/1976, fl., Miotto et al. 235 (ICN); Santo Antão, 2/XI/1950, fl., Beltrão s.n. (SMDB 589); Santo Antônio das Missões, 10/XII/1976, fl. fr., Miotto et al. 303 (ICN); São Francisco de Assis, Arroio Piraju, 16/I/1991, fl., Machado et al. 1119 (SMDB); São Luiz Gonzaga, São Lorenço das Missões, 8/IV/2000, fl. fr., Rodrigues \& Flores 973 (ICN); São Miguel das Missões, 10/XII/1976, fl., Miotto et al. 269 (ICN).

Originária desde o México até o Brasil e Uruguai (Irwin \& Barneby 1982). No Estado, cresce em campo limpo e em vegetação secundária.Das três variedades aceitas por Irwin \& Barneby (1982), no Rio Grande do Sul ocorre apenas S. pilifera var. pilifera.

17. Senna scabriuscula (Vogel) H.S. Irwin \& Barneby, Mem. New York Bot. Gard. 35(1): 435. 1982. Cassia occidentalis var. (y?) scabriuscula Vogel, Gen. Cass. syn. 21. 1837.

Fig. 23-25.

Subarbustos, até $1 \mathrm{~m}$ alt., ramos glabrescentes ou pubérulos. Estípulas triangulares, 2-4mm compr. Folhas 5-7 pares de folíolos, $6-19 \mathrm{~cm}$ compr.; pecíolo 0,8-1,8(-2,2)cm compr.; glândulas presentes na base do pecíolo, ovóides, sésseis; folíolos lanceolados ou oval-lanceolados, ápice agudo, base levemente oblíqua ou cuneada, folíolo distal $3-9 \times 0,8-1,2 \mathrm{~cm}$, face adaxial glabra ou glabrescente e abaxial pubescente. Racemos axilares, 3-9 flores; pedúnculo 5-10mm compr.; brácteas lanceoladas, $5-7 \mathrm{~mm}$ compr., caducas. Pedicelo $12-16 \mathrm{~mm}$ compr. Sépalas $7-11 \mathrm{~mm}$ compr.; corola zigomorfa, amarela, pétalas $15-18 \mathrm{~mm}$ compr.; 4 estames medianos com filetes $3 \mathrm{~mm}$ compr. e anteras $5 \mathrm{~mm}$ compr., estames abaxiais com anteras anisomórficas, estame centro-abaxial reduzido a estaminódio com filete $4 \mathrm{~mm}$ compr. e antera $2 \mathrm{~mm}$ compr., 2 estames latero-abaxiais com filetes $7-8 \mathrm{~mm}$ compr. e anteras $8-9 \mathrm{~mm}$ compr., bico $2 \mathrm{~mm}$ compr.; gineceu $15 \mathrm{~mm}$ compr., ovário pubescente. Legumes comprimidos, endocarpo seco, ascendentes, ligeiramente curvos, glabrescentes, $11 \times 0,5 \mathrm{~cm}$. Sementes não vistas.

Material selecionado: BRASIL. Rio Grande do Sul: Dois Lageados, 29/I/1998, fl., Knob \& Bordignon 
5516 (UNILASALLE); Guaíba, 13/III/1964, fl., Kappel et al. s.n. (BLA 4024). Pelotas, Laranjal, 7/III/1956, fr., Schultz 2980 (ICN); Rio Grande, 2/II/1970, fl., Ferreira 539 (ICN). Id., Trevo, 2/III/1998, fl., Neves s.n. (HURG 1591); São Francisco de Assis, 15/I/1991, fr., Machado et al. 1083 (SMDB).

Ocorre na Bolívia, Paraguai, Argentina e Uruguai (Irwin \& Barneby 1982; Fortunato 1999). É mencionada pela primeira vez para o Estado, onde ocorre em campo arenoso e vegetação secundária. Espécie rara e com baixa freqüência no Estado. É uma espécie muito similar a $S$. occidentalis, da qual se diferencia pelo comprimento das brácteas e pecíolos e por possuir estípulas geralmente menores e folhas mais estreitas, com superfície abaxial pubescente.
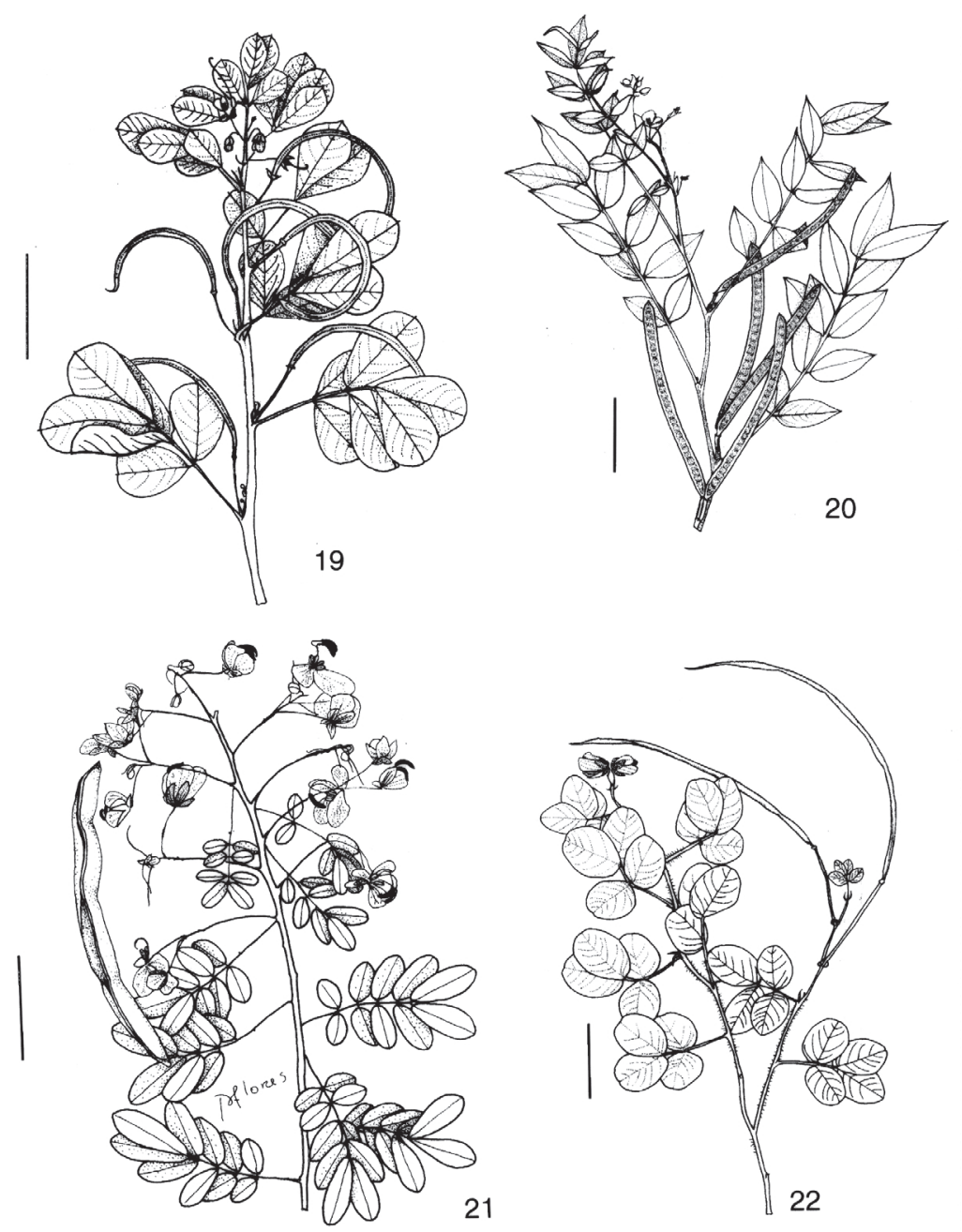

Figuras 19-22. 19. Senna obtusifolia (L.) H.S. Irwin \& Barneby; ramo com flores e frutos (Rodrigues \& Flores 979). 20. Senna occidentalis (L.) Link; ramo com flores e frutos (Flores \& Rodrigues 400). 21. Senna pendula (Willd.) H.S. Irwin \& Barneby; ramo com flores e frutos (Flores \& Rodrigues 399). 22. Senna pilifera (Vogel) H.S. Irwin \& Barneby; ramo com flores e frutos (Rodrigues \& Flores 973). (Escalas dos hábitos $5 \mathrm{~cm}$ ).

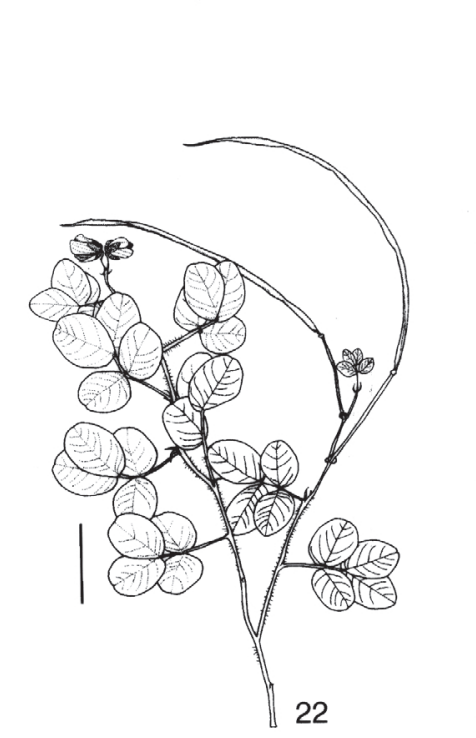

18. Senna siamea (Lam.) H.S. Irwin \& Barneby, Mem. New York Bot. Gard. 35(1): 98. 1982.

Cassia siamea Lam., Encycl. 1(2): 648. 1785.

Fig. 26-27.

Árvores, eretas, 4-7m alt., ramos glabrescentes. Estípulas subuladas, $1 \mathrm{~mm}$ compr. Folhas 6-7 pares de folíolos, 12-16,5cm compr.; pecíolo 2,2-3cm compr.; glândulas ausentes; folíolos oblongos ou oblongoelípticos, ápice obtuso ou retuso, base cuneada ou ligeramente oblíqua, folíolo distal 4-5,7×1,5-2,4cm, com ambas as faces glabras ou pubérulas. Racemos axilares corimbiformes ou panículas terminais, 21-31 flores por racemo; pedúnculo $2-3 \mathrm{~cm}$ compr.; brácteas falcadas, $4 \mathrm{~mm}$ compr., caducas. Pedicelo 23-35mm compr. Sépalas 5-10mm compr.; corola zigomorfa, amarela, pétalas $10-18 \mathrm{~mm}$ compr.; 4 estames medianos com 
filetes $2-3 \mathrm{~mm}$ compr. e anteras $6 \mathrm{~mm}$ compr., estames abaxiais com anteras isomórficas, estame centroabaxial com filete $5 \mathrm{~mm}$ compr. e antera $6 \mathrm{~mm}$ compr., 2 estames latero-abaxiais com filetes $8-12 \mathrm{~mm}$ compr. e anteras 6-7mm compr., bico ausente; gineceu $16 \mathrm{~mm}$ compr., ovário pubescente. Legumes comprimidos, endocarpo seco, pêndulos, retos, pubérulos, $15-16,5 \times 1 \mathrm{~cm}$. Sementes não vistas.

Material selecionado: BRASIL. Rio Grande do Sul: Canoas, 19/IV/2002, fl., Rodrigues \& Flores 1455 (ICN); Porto Alegre, 27/III/1978, fl., Medeiros s.n. (ICN 44006).

Originária de Burma e Tailândia, amplamente cultivada como ornamental nas regiões tropicais da América (Irwin \& Barneby 1982). As medidas dos frutos foram obtidas a partir de material imaturo.
19. Senna spectabilis (DC.) H.S. Irwin \& Barneby, Mem. New York Bot. Gard. 35(2): 600. 1982.

Cassia spectabilis DC., Cat. pl. horti monsp. 90. 1813.

Fig. 28-29.

Árvores, eretas, 5-7m alt., ramos glabros ou pubérulos. Estípulas lineares, $4-7 \mathrm{~mm}$ compr. Folhas 9-12 pares de folíolos, $17,5-21 \mathrm{~cm}$ compr.; pecíolo 2,5-3,2cm compr.; glândulas ausentes, folíolos ovais ou oblongo-elípticos, ápice agudo ou obtuso, base oblíqua, folíolo distal 4,5-5,5×1,7-2,4cm, ambas as faces glabrescentes ou pubérulas. Racemos axilares ou panículas terminais, 18-30 flores por racemo; pedúnculo 26-40mm compr.; brácteas linear-lanceoladas, 3,5-4mm compr., caducas. Pedicelo 17-25mm compr. Sépalas 3-6mm compr.; corola assimétrica, amarela,

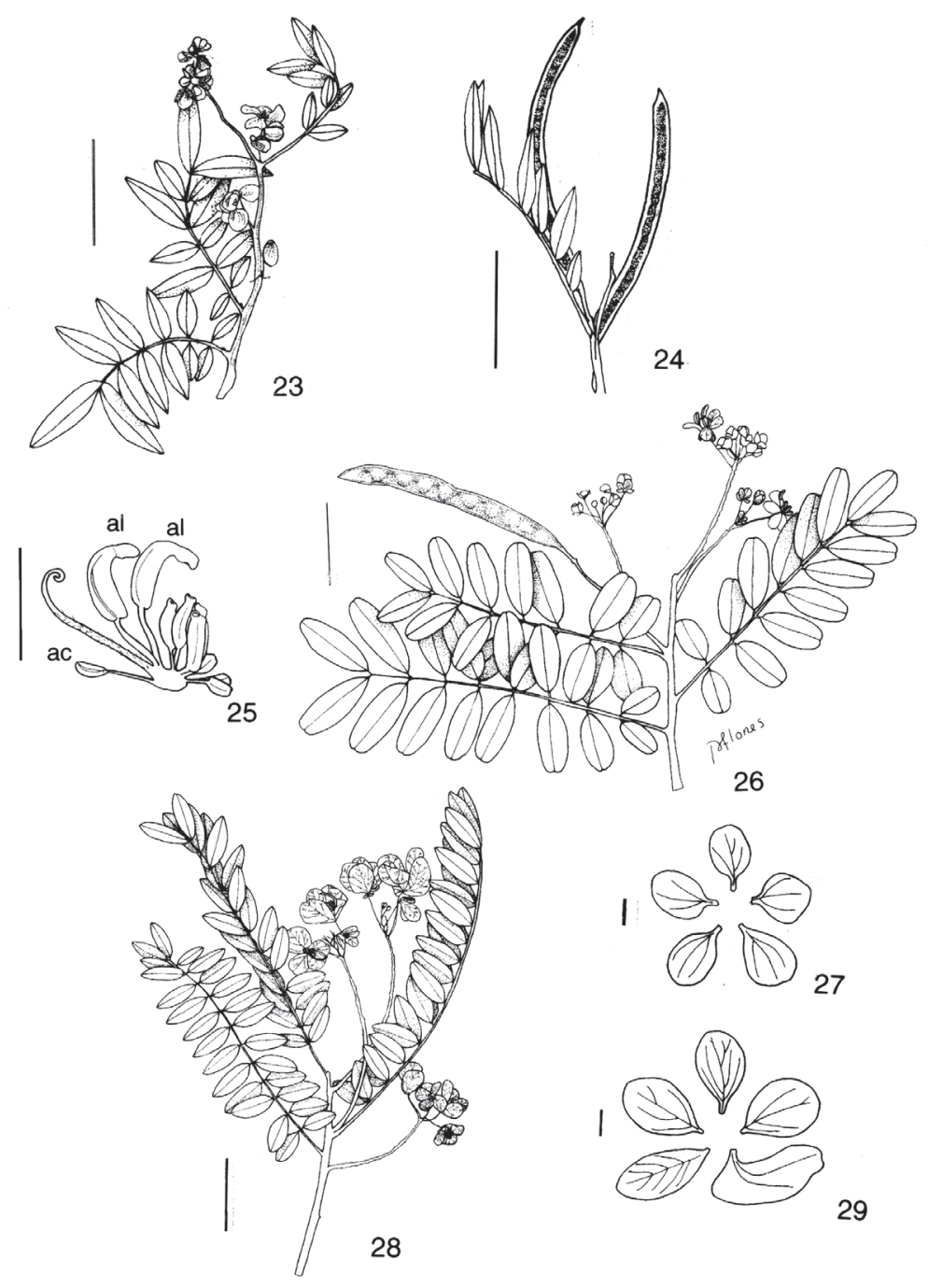

Figuras 23-29. 23-25. Senna scabriuscula (Vogel) H.S. Irwin \& Barneby. 23. Ramo com flores. 24. Ramo com frutos (Schultz 2980). 25. Androceu (Ferreira 539). 26-27. Senna siamea (Lam.) H.S. Irwin \& Barneby. 26. Ramo com flores e frutos. 27. Pétalas (Rodrigues \& Flores 1455). 28-29. Senna spectabilis (DC.) H.S. Irwin \& Barneby. 28. Ramo com flores. 29. Pétalas (Rodrigues \& Flores 1454). (Abreviaturas: ac - estame centro-abaxial; al - estames latero-abaxiais; escalas dos detalhes $1 \mathrm{~cm}$, hábitos $5 \mathrm{~cm}$ ). 
pétalas $14-27 \mathrm{~mm}$ compr.; 4 estames medianos com filetes 2,1-2,5mm compr. e anteras 5-6mm compr., estames abaxiais com anteras isomórficas, estame centro-abaxial com filete $2,2-2,5 \mathrm{~mm}$ compr. e antera $5,2-5,7 \mathrm{~mm}$ compr., 2 estames latero-abaxiais com filetes $2,2-2,5 \mathrm{~mm}$ compr. e anteras $5,5-5,7 \mathrm{~mm}$ compr., com bico curvo, $0,5 \mathrm{~mm}$ compr.; gineceu $17-19 \mathrm{~mm}$ compr., ovário glabro. Legumes quadrangulares, endocarpo seco, pêndulos, retos, glabros, 15-23 $\times 1-1,3 \mathrm{~cm}$. Sementes 1-seriadas, ovais, oliváceas, $5-7,2 \times 4-5,5 \mathrm{~mm}$.

Material selecionado: BRASIL. Rio Grande do Sul: Osório, RS 389 km 5, 19/IV/2002, fl., Rodrigues \& Flores 1454 (ICN); Porto Alegre, Parque Marinha do Brasil, 31/III/2001, fl., Flores \& Rodrigues 504 (ICN, UEC); Santa Maria, Itaara, 10/III/1994, fl., Romero s.n. (SMDB 6193).

Ocorre do México até a Argentina, sendo amplamente cultivada como ornamental nos neotrópicos (Irwin \& Barneby 1982). É mencionada pela primeira vez para o Estado, onde é pouco cultivada.

\section{Agradecimentos}

Agradecemos à Patrícia S. Flores, pela elaboração das ilustrações; à Roseli L.C. Bortoluzzi, pelo intercâmbio de informações; à Regina Lerina, pela atenção aos pedidos de empréstimo; aos revisores do trabalho, pela leitura crítica do manuscrito; aos curadores dos herbários consultados, pelo empréstimo de material. Sílvia T.S. Miotto, ao CNPq (Bolsa Produtividade) e PRONEX/FINEP.

\section{Referências bibliográficas}

Bravo, L.D. 1978. El género Cassia en la Argentina, I. Serie Aphyllae. Darwiniana 21(2-4): 343-391.
Bridson, G.D.R. \& Smith, E.R. 1991. Botanicum-PeriodicumHuntianum/Supplementum. Pittisburgh, Hunt Institute for Botanical Documentation.

Brummitt, R.K. \& Powell, C.E. 1992. Authors of Plant Names. Kew, Royal Botanic Gardens.

Burkart, A. 1987. Senna. Pp. 510-518. In: A. Burkart (ed.). Flora Ilustrada de Entre Ríos (Argentina). Colecc. Ci. Inst. Nac. Tecnol. Agropecu. 6(3a).

Dimitri, M. J. \& Alberti, F. R. 1954. Las especies del género Cassia cultivadas en la Argentina. Revista Invest. Agríc. 7(1): 5-34.

Fortunato, R.H. 1999. Senna. Pp. 728-731. In: F. Zuloaga \& O. Morrone (eds.). Catalogo de las Plantas Vasculares de la Republica Argentina, II (A-E) \& (F-Z). Monographies Systematic of the Missouri Botanical Garden 74.

Holmgren, P.K.; Holmgren, N.H. \& Barnett, L.C. 1990. Index Herbariorum, part 1: The herbaria of the world. 8 ed. New York, The New York Botanical Garden Press.

Irwin, H.S. \& Barneby, R.C. 1981. Tribe Cassieae Bronn. Pp. 97-106. In: R.M. Polhill \& P. H. Raven (eds.). Advances in legume systematics. Part 1, Kew, The Royal Botanic Gardens.

Irwin, H.S. \& Barneby, R.C. 1982. The American Cassinae, a synoptical revision of Leguminosae, Tribe Cassieae, subtribe Cassinae in the New World. Memoires of the New York Botanical Garden 35(1-2): 1-918.

Lawrence, G.H.M.; Buchheim, A.F.G.; Daniels, G.S. \& Dolezal, H. 1968. Botanicum-Periodicum-Huntianum. Pittisburgh, Hunt Botanical Library.

Lorenzi, H. 1992. Árvores brasileiras: manual de identificação e cultivo de plantas arbóreas nativas do Brasil. Nova Odessa, Editora Plantarum.

Mattos, N.F. 1983. Leguminosae-Caesalpinioideae do Rio Grande do Sul. Roessléria 5(1): 3-74.

Rambo, B. 1966. Leguminosae Riograndenses. Pesquisas, Botanica 23: 1-166.

Reveal, J.L. 1991. Lectotypification of Cassia occidentalis Linnaeus (Caesalpiniaceae). Phytologia 71(6): 453-455.

Simões, C.M.O.; Mentz, L.A.; Schenkel, E.P.; Irgang, B.E. \& Stehmann, J.R. 1995. Plantas da Medicina Popular no Rio Grande do Sul. 4 ed. Porto Alegre, Editora da Universidade Federal do Rio Grande do Sul.

Stafleu, F.A. \& Cowan, R.S. 1976-1988. Taxonomic Literature. 2 ed. v. I-VII. Bohn, Utrecht, Scheltema \& Holkema. 